\title{
HUBUNGAN HUKUM ANTARA BUKALAPAK SEBAGAI MARKETPLACE DENGAN PENJUAL SEBAGAI MERCHANT (Studi di Bukalapak.com)
}

\author{
Jasmine Adhwaisy Meifriday \\ E-mail: jasmineadhwaisy@student.uns.ac.id \\ Mahasiswa Fakultas Hukum Universitas Sebelas Maret Surakarta \\ Pranoto \\ E-mail: maspran7@gmail.com \\ Dosen Fakultas Hukum Universitas Sebelas Maret Surakarta
}

\begin{abstract}
This article aims to determine the legal relationship between Bukalapak as a marketplace with seller as a merchant in the marketplace Bukalapak and to find out how the legal consequence from the legal relationship between Bukalapak as a marketplace with seller as a merchant in the marketplace Bukalapak. This legal research method used in this legal writing include normative type of research, and source of legal materials used were the primary law and secondary law by way of literature/ documents. The results of this study, it is known that the legal relationship between Bukalapak as a marketplace with seller as a merchant in the marketplace Bukalapak has not met entirely a legality of the transaction pursuant to Article 1320 of the civil code and Undang-Undang Nomor 11 Tahun 2008 regarding the information and online transaction. Which is in every legal relationship between the participate there must be a legal consequence.
\end{abstract}

Keywords: Legal Relationship; Marketplace; Legal Consequence

\begin{abstract}
Abstrak
Artikel ini bertujuan untuk mengetahui hubungan hukum antara Bukalapak sebagai marketplace dengan penjual sebagai merchant di marketplace Bukalapak serta untuk mengetahui akibat hukum dari hubungan hukum antara Bukalapak sebagai marketplace dengan penjual sebagai merchant di marketplace Bukalapak. Penulisan hukum ini merupakan penelitian hukum normatif dan bahan hukum menggunakan bahan hukum primer dan bahan hukum sekunder yang berkaitan dengan isu hukum yang dikaji dengan cara studi pustaka atau dokumen. Hasil penelitian ini, telah diketahui bahwa hubungan hukum antara Bukalapak sebagai marketplace dengan penjual sebagai merchant di marketplace Bukalapak sepenuhnya belum memenuhi syarat dengan sebagaimana diatur dalam ketentuan $\mathrm{KUH}$ Perdata Pasal 1320 serta Undang-Undang Nomor 11 Tahun 2008 tentang Informasi dan Transaksi Elektronik. Yang mana dalam setiap hubungan hukum para pihak pasti terjadi suatu akibat hukum.
\end{abstract}

Kata Kunci: Hubungan Hukum; Marketplace; Akibat Hukum

\section{A. Pendahuluan}

Pencapaian teknologi internet yang pesat dan maju, mempermudah untuk mengakses informasi apapun yang dibutuhkan, termasuk di dalamnya informasi produk. Adanya kemudahan tersebut membuatnya menjadi suatu potensi yang sangat penting untuk dapat mempengaruhi pola perdagangan. Kemampuan komputer-komputer tersebut untuk saling terkoneksi antar satu dengan lainnya membuka peluang munculnya suatu metode pemasaran baru bagi produk- produk perniagaan baik itu berupa barang maupun jasa. Metode pemasaran atau jual beli melalui internet ini dikenal dengan istilah electronic commerce (e-commerce). Saat ini memang belum ada definisi pasti e-commerce yang sudah distandarkan dan disepakati bersama, namun dalam pengertian umum yang diterima masyarakat, e-commerce merupakan perdagangan yang dilakukan melalui internet (Dadang Kusbiantoro, 2012:1-2). 
Dengan kemampuan web/internet yang bisa mengirimkan berbagai bentuk data seperti teks, grafik, gambar, suara, animasi, atau bahkan video, maka banyak kalangan bisnis yang memanfaatkan teknologi ini dengan membuat homepage untuk mempromosikan usahanya (Freimut Bodendorf, 2009).

Pemanfaatan teknologi telah mendorong pertumbuhan bisnis yang cepat, karena berbagai informasi dapat disajikan melalui hubungan jarak jauh dan mereka yang ingin mengadakan transaksi tidak harus bertemu muka, akan tetapi cukup melalui peralatan komputer dan telekomunikasi. Perkembangan teknologi informasi juga membentuk masyarakat dunia baru yang tidak lagi dihalangi oleh batas-batas teritorial dan telah membalikkan segalanya yang jauh jadi dekat yang khayal jadi nyata (Latifah Hanim, 2011:60).

E-commerce tidak dapat terlepas dari adanya marketplace yang memberikan kemudahan dalam melakukan kegiatan transaksi jual beli (Yosi Krisharyawan, 2015:144). Dalam UU ITE tersebut perjanjian elektronik merupakan salah satu bentuk perjanjian baru yang mendapatkan perlindungan secara khusus dalam Undang-Undang Nomor 11 Tahun 2008 tentang Informasi dan Transaksi Elektronik (yang selanjutnya disebut UU ITE), khususnya melalui Pasal 1 angka 17 , kontrak elektronik adalah perjanjian para pihak yang dibuat melalui sistem elektronik.

Di sisi lain, timbul kompleksitas baru dari digitalisasi ekonomi ini. Ekses yang dihasilkan tak pasti akan timbul hubungan hukum. Serta dalam artian akan timbul akibat hukum dari potensi permasalahan hubungan hukum mulai dari marketplace sebagai penyedia toko online dengan penjual sebagai merchant, karena tidak mengetahui secara pasti seperti apa hubungan hukum yang harusnya terjadi di antara kedua belah pihak tersebut. Salah satunya dengan adanya suatu perjanjian yang tidak terpenuhi seperti penjual mengirimkan barang hanya kotak kayu yang tidak sesuai dengan yang telah pembeli pesan yaitu iPhone 6S. (https://komunitas.Bukalapak. com diakses pada tanggal 18 juni 2019). Permasalahan tersebut dapat dikatakan melanggar syarat dan ketentuan yang berlaku di Bukalapak, sehingga timbul akibat hukum dari hubungan hukum antara Bukalapak sebagai marketplace dengan penjual sebagai merchant.

Berdasarkan pendahuluan tersebut, maka dalam artikel ini membahas tentang hubungan hukum antara Bukalapak sebagai Marketplace dengan penjual sebagai Merchant dan mengetahui akibat hukum dari hubungan hukum antara Bukalapak sebagai Marketplace dengan penjual sebagai Merchant.

\section{B. Metode Penelitian}

Metode penelitian yang digunakan adalah penelitian hukum normatif bersifat preskriptif dan terapan. Sumber bahan hukum yang digunakan adalah bahan hukum primer dan bahan hukum sekunder, dengan cara studi pustaka/dokumen, teknik analisis bahan hukum menggunakan metode silogisme dan interpretasi dengan menggunakan pola berpikir deduktif, dari pengajuan premis mayor dan premis minor saling dihubungkan untuk ditarik konklusi.

\section{Hasil Penelitian dan Pembahasan}

Hubungan hukum dapat terjadi antara sesama subyek hukum dan antara subyek hukum dengan benda. Hubungan antara sesama subyek hukum dapat terjadi antara orang, orang dengan badan hukum, dan antara sesama badan hukum. Hubungan hukum antara subyek hukum dengan benda berupa hak apa yang dikuasai oleh subyek hukum itu atas benda tersebut, baik benda berwujud, benda bergerak, atau benda tidak bergerak (Peter Mahmud Marzuki.2012:254).

Bukalapak.com (selanjutnya disebut "Bukalapak") adalah suatu perseroan terbatas yang salah satu jenis usahanya bergerak di bidang jasa portal web. Bukalapak dalam hal ini menyediakan Platform perdagangan elektronik (e-commerce) dimana Pengguna dapat melakukan transaksi jual beli barang dan menggunakan berbagai fitur serta layanan yang tersedia. Sebagai penunjang bisnis dan marketp/ce perdagangan elektronik, Bukalapak menjamin keamanan dan kenyamanan 
bagi para Pengguna. Bukalapak merupakan situs layanan jual-beli online dengan model bisnis consumer to consumer (C2C). Bukalapak termasuk dalam kerjasama marketplace murni.

Dalam suatu hubungan hukum terdapat adanya perjanjian yang diperlukan untuk menyatakan persetujuan dari para pihak terhadap suatu kontrak. Pengaturan mengenai kontrak elektronik antara penjual sebagai merchant dengan Bukalapak sebagai Marketplace mengenai hukum yang berlaku di Indonesia seperti syarat sah perjanjian sudah diatur di dalam Peraturan Pemerintah Nomor 82 Tahun 2012 tentang Penyelenggaraan Sistem dan Transaksi Elektronik yaitu dalam Pasal 47 ayat (2) syarat sah suatu perjanjian yaitu:

1. terdapat kesepakatan para pihak;

2. dilakukan oleh subjek hukum yang cakap atau yang berwenang mewakili sesuai dengan ketentuan peraturan perundang-undangan;

3. terdapat hal tertentu; dan

4. objek transaksi tidak bertentangan dengan peraturan perundang- undangan.

E-contract itu sendiri menurut Pasal 48 Ayat (3) PP PSTE setidaknya memuat:

1. data identitas para pihak;

2. objek dan spesifikasi;

3. persyaratan Transaksi Elektronik;

4. harga dan biaya;

5. prosedur dalam hal terdapat pembatalan oleh para pihak;

6. ketentuan yang memberikan hak kepada pihak yang dirugikan untuk dapat mengembalikan barang dan/atau meminta penggantian produk jika terdapat cacat tersembunyi; dan

7. pilihan hukum penyelesaian Transaksi Elektronik.

Syarat sahnya perjanjian diatur di dalam Pasal 1320 KUHPerdata yang menyatakan bahwa terdapat empat syarat sah keabsahan suatu perjanjian yaitu:

1. Sepakat mereka yang mengikatkan dirinya

Di Bukalapak kesepakatan penjual mengikatkan diri terhadap marketpalce ini tetap berpegang pada teori terjadinya suatu kesepakatan. Salah satu teori yang dapat digunakan penulis adalah teori penawaran dan penerimaan. Bahwa penawaran (offer) itu sendiri adalah peryataan salah satu pihak. Offeror, untuk masuk dalam ikatan suatu perjanjian (Mariam Darrus B,2011:33). Dalam konteks online, sebuah website atau jasa online seperti Bukalapak dapat memasang informasi produk yang mereka tawarkan, dimana informasi tersebut berupa katalog produk dan layanan yang mereka berikan.

2. Kecakapan dalam membuat suatu perikatan

Problematika yang terdapat di Bukalapak mengenai syarat sah kecakapan adalah belum adanya syarat atau ketentuan yang dapat menyatakan bahwa orang yang menjadi penjual di Bukalapak itu memang benar-benar sudah cakap untuk melakukan e-contract. Real nya seseorang yang melakukan e-contract ini tidak perlu menunjukkan identitas usianya, sehingga tidak dapat diketahui bahwa yang melakukan perjanjian tersebut adalah seseorang yang cakap atau tidak. Biodata yang diserahkan ke Bukalapak melalui pembuatan akun tersebut sangat mudah dikelabuhi dimana dalam pembuatan akun Bukalapak.

3. Mengenai suatu hal tertentu

Dalam ketentuan tersebut masih ada merchant yang tidak serta merta menampilkan barang dengan informasi yang benar-benar lengkap sesuai yang telah diatur pada syarat dan ketentuan di Bukalapak. Sebagai marketplace, Bukalapak juga tetap tidak dapat melihat dengan real bagaimana bentuk atau spesifikasi barang yang telah di pasang pada lapak merchant. Dalam hal tersebut terdapat keterbatasan informasi. Maka sesuai syarat dan ketentuan yang telah diatur di Bukalapak, bawa penjual harus bertanggung jawab penuh atas segala resiko yang timbul dengan informasi yang telah diberikan oleh penjual yang telah dipasang pada merchant mereka di platform Bukalapak. 
4. Suatu sebab yang halal

Melakukan e-contract terdapat sebuah klausula kontrak yang mana kontrak tersebut dapat memberikan bukti bahwa e-contract tidak berbeda dengan perjanjian konvensional. Penjual dapat menggunakan platform Bukalapak dengan melihat isi syarat dan ketentuan yang berada di situs Bukalapak.

Menurut (Onno W. Purbo dan Arif Wahyudi,2001), proses transaksi jual beli online (e-commerce) pada dasarnya ada lima tahap yang runtut (Yahya Ahmad Zein, 54-55), dan jika dikaitkan dengan Bukalapak maka lima tahapan tersebut adalah sebagai berikut:

1. Find it

Dalam tahap ini Situs Bukalapak yang beralamat di www.Bukalapak.com menampilkan beberapa produk yang dijual di dalam marketplace tersebut, selain itu juga para merchant yang telah bergabung telah menjual barang sesuai kriteria dan syarat yang telah diatur di Bukalapak kecuali barang terlarang. Barang terlarang adalah barang yang dilarang diperjualbelikan di marketplace Bukalapak berdasarkan peraturan perundang-undangan yang berlaku di Republik Indonesia dan kebijakan internal Bukalapak. Selain itu terdapat kolom search untuk memudahkan konsumen mencari barang yang dituju, pengelompokan barang yang terdiri dari berbagai kategori dan juga kolom search itu dapat memudahkan konsumen untuk menerima informasi seputar produk yang ditawarkan.

2. Explore it

Di Bukalapak, penjual harus pandai dalam penggunaan merchant mereka. Dalam tahap ini penjual harus dapat merincikan ukuran, warna, dan barang yang tersedia sesuai peraturan di syarat dan kententuan yang telah marketplace Bukalapak tentukan pada angka 6: "Penjual wajib memisahkan tiap-tiap barang yang memiliki ukuran dan harga yang berbeda."

3. Select it

Pada situs Bukalapak apabila pembeli tertarik dengan sebuah barang maka dapat di klik "beli sekarang" untuk menunjukkan bahwa pembeli tertarik dengan produk tersebut dan berniat untuk membeli barang tersebut. Dalam hal ini setelah pembeli meng-klik "beli sekarang" maka barang tersebut masuk terlebih dahulu ke shopping cart dan pembeli dapat melihat produk produk lainnya yang diinginkan, dan dapat menyimpan barang dalam shopping cart kembali sampai pembeli menyeleksi barang yang ingin benar- benar dibeli, ataupun pembeli dapat membeli semua barang yang ada di dalam shopping cart nya. Setelah itu muncul kembali rincian harga beserta detail produk yang dipilih, seperti warna atau ukuran yang dipilih.

4. Buy it

Setelah tahapan di atas sudah dilakukan, lakukan, selanjutnya dilakukan proses check out, pada tahap ini dilakukan proses transaksi pembayaran setelah terlebih dahulu mengisi formulir yang telah disediakan merchant. Untuk metode pembayaran instan (Credits, Transfer Virtual Account, Kartu Visa/Mastercard/JCB, Akulaku, Kredivo, DANA, BCA Klikpay, CIMBClicks/RekPonsel/QRGoMobile, Indomaret, Alfamart, Pos Indonesia, BRI E-Pay, dan Mitra Bukalapak), verifikasi pembayaran dilakukan secara otomatis oleh sistem setelah pembayaran transaksi berhasil dilakukan.

5. Ship it

Dalam hal pengiriman Bukalapak bekerja sama dengan Partner Ekspedisi Pengiriman Barang Resmi untuk menyediakan pilihan metode pengiriman barang, bagi para Pengguna baik Pembeli maupun Penjual, kecuali untuk Layanan Ambil Sendiri. Adapun Partner Ekspedisi Pengiriman Barang Resmi di Bukalapak, antara lain Ninja Express, Tiki, J\&T, Go-Send, Pos Indonesia, SiCepat, Grab, JNE, Wahana, Alfatrex, Lion Parcel.

Suatu hubungan hukum antara Bukalapak sebagai Marketplace dengan penjual sebagai merchant pasti dapat terjadi akibat hukum. Bahwa dari perbuatan yang dilakukan subyek hukum terhadap obyek hukum menimbulkan akibat hukum. Akibat hukum itu dapat berwujud: 
1. Lahirnya, berubahnya atau lenyapnya suatu keadaan hukum.

Usia menjadi 21 tahun, akibat hukumnya berubah dari tidak cakap hukum menjadi cakap hukum, atau anak di bawah 21 tahun ingin berbelanja di Marketplace Bukalapak tetapi dengan adanya pengampuan, lenyaplah kecakapan melakukan tindakan hukum.

2. Lahirnya, berubahnya atau lenyapnya suatu hubungan hukum, antara dua atau lebih subyek hukum, di mana hak dan kewajiban pihak yang satu berhadapan dengan hak dan kewajiban pihak yang lain.

Penjual di situs Bukalapak mengadakan perjanjian jual beli dengan Pembeli, maka lahirlah hubungan hukum antara Penjual dan Pembeli. Setelah dibayar lunas dan barang datang sesuai pesanan, maka hubungan hukum tersebut menjadi lenyap.

3. Lahirnya sanksi apabila dilakukan tindakan yang melawan hukum.

Seorang penjual mendapat sanksi hukum karena penjual tersebut melanggar syarat dan ketentuan yang sudah diberikan dari Bukalapak yaitu dengan mengirim barang tidak sesuai yang tertera pada merchant si penjual tersebut. Penjual tersebut mengambil hak, kewajiban pembeli tersebut dan melawan hukum.

Melakukan hubungan hukum antara Bukalapak sebagai marketplace dengan penjual sebagai merchant. Hukum perdata memungkinkan seseorang bertanggung jawab bukan karena dia bersalah, tetapi karena dia mengambil risiko dalam kedudukan hukumnya sedemikian rupa yang mewajibkannya bertanggung jawab. Inilah yang disebut dengan tanggung jawab atas dasar risiko. Keduanya menimbulkan akibat dan konsekuensi yang jauh berbeda. (Janus Sidabok, 2014 : 90-91)

1. Tanggung jawab berdasarkan unsur kesalahan

Prinsip ini menyatakan, seseorang baru dapat dimintakan pertanggungjawabannya secara hukum jika ada unsur kesalahan yang dilakukannya. Pasal 1365 KUHPerdata, yang lazim dikenal sebagai pasal tentang perbuatan melanggar hukum, mengharuskan terpenuhinya empat unsur pokok, yaitu:
a. adanya perbuatan;
b. adanya unsur kesalahan;
c. adanya kerugian yang diderita;
d. adanya hubungan kausalitas antara kesalahan dan kerugian.

2. Praduga untuk selalu bertanggung jawab prinsip ini menyatakan, tergugat selalu dianggap bertanggung jawab (presumption of liability principle), sampai ia dapat membuktikan ia tidak bersalah. Jadi, beban pembuktian ada pada si tergugat. (Celina Tri Siwi, 2017 :94).

3. Praduga untuk tidak selalu bertanggung jawab

Prinsip ini adalah kebalikan dari prinsip kedua. Prinsip praduga untuk tidak selalu bertanggung jawab (presumption nonliability principle) hanya dikenal dalam lingkup transaksi konsumen yang sangat terbatas.

4. Tanggung jawab mutlak.

Penjual wajib bertanggung jawab atas kerugian yang diderita konsumen atas penggunaan produk yang dipasarkannya. Gugatan product liability dapat dilakukan berdasarkan tiga hal (Celina Tri Siwi Kristiyanti, 2017:97):

a. melanggar jaminan (breach of warranty), misalnya khasiat yang timbul tidak sesuai dengan janji yang tertera dalam kemasan produk;

b. ada unsur kelalaian (negligence), yaitu produsen lalai memenuhi standar pembuatan obat yang baik;

c. menerapkan tanggung jawab mutlak (strict liability). 
5. Tanggung jawab dengan pembatasan

Prinsip tanggung jawab ini sangat merugikan konsumen bila ditetapkan secara sepihak oleh pelaku usaha. Dalam Undang-Undang Nomor 8 Tahun 1999 tentang Perlindungan Konsumen seharusnya pelaku usaha tidak boleh secara sepihak menentukan klausul yang merugikan konsumen, termasuk membatasi maksimal tanggung jawabnya. Jika ada pembatasan mutlak harus berdasarkan pada peraturan perundang-undangan yang jelas.

Dalam kasus ini penjual seharusnya bertanggung jawab atas kerugian yang diderita oleh Marketplace Bukalapak serta konsumen.

\section{Simpulan}

1. Hubungan hukum antara Bukalapak sebagai marketplace terhadap penjual sebagai merchant di dalam marketplace Bukalapak belum sepenuhnya memenuhi suatu syarat sah perjanjian jual beli sesuai dengan Pasal 47 ayat (2) Peraturan Pemerintah Nomor 82 Tahun 2012 tentang Penyelenggaraan Sistem dan Transaksi Elektronik yang berpedoman pada Pasal 1320 KUHPerdata. Transaksi jual beli online memang sulit diaplikasikan seperti pada transaksi jual beli konvensional pada umumnya karena hanya terbatas pada jaringan internet tanpa harus bertatap muka.

2. Akibat hukum atas hubungan hukum antara Bukalapak sebagai marketplace dengan penjual sebagai merchant terjadi karena adanya suatu transaksi elektronik di Bukalapak antara penjual yang mengirimkan kayu sedangkan pembeli memesan iPhone 6s sehingga timbul adanya tanggung jawab yang harus dilaksanakan oleh penjual kepada pembeli dan Bukalapak dari permasalahan tersebut.

\section{E. Saran}

1. Bukalapak diharapkan dalam pelaksanaan syarat dan ketentuan yang terdapat di website Bukalapak.com dibuat dalam satu rangkaian transaksi jual beli sehingga ketika ada pembeli yang melakukan transaksi jual beli dapat dengan mudah mendapatkan maupun melihat syarat dan ketentuan sebagai kontrak elektronik tersebut.

2. Bukalapak melakukan sosialisasi mengenai transaksi komersial elektronik kepada masyarakat dan para penegak hukum agar masyarakat dan para penegak hukum memahami mekanisme dan permasalahan yang berkaitan dengan transaksi komersial elektronik (e-commerce) dan menyiapkan infrastruktur dan sumber daya manusia yang baik untuk mendukung perkembangan transaksi komersial elektronik (e-commerce) di Indonesia maupun cara dan bagaimana penyelesaiannya baik melalui pengadilan untuk penyelesaian sengketa yang terjadi akibat meningkatnya transaksi elektonik di Indonesia serta agar patuh pada peraturan yang berlaku.

\section{F. Daftar Pustaka}

Celina Tri Siwi Kristiyanti. 2017. Hukum Perlindungan Konsumen. Jakarta : Sinar Grafika.

Dadang Kusbiantoro. 2012. "Tinjauan Yuridis terhadap Klausula Baku pada Perjanjian Pembelian Buku Secara Online (E-Commerce) di Bukabuku.com dan Blibli.com Menurut Undang-Undang Nomor 8 Tahun 1999 tentang Perlindungan Konsumen". Skripsi. Depok: Fakultas Hukum Universitas Indonesia.

Donald H Sanders. 1985. Computer Today, Second Edition, chapter1. (New York: Mc. Graw Hill)

Freimut Bodendorf and Florian Lang. 2009. Automed Services for Market-Based E-commerce Transaction. Proceedings of the International Multiconference of Engineers and Computer Scientist 2009 Vol I IMECS 2009. March 18-19 2009. Hongkong 
Janus Sidabalok. 2014. Hukum Perlindungan Konsumen di Indonesia. Bandung: PT Citra Aditya Bakti.

Latifah Hanim. 2011. "Pengaruh Perkembangan Teknologi Informasi terhadap Keabsahan Perjanjian dalam Perdagangan secara Elektronik (E-Commerce) di Era Globalisasi”. Jurnal Dinamika Hukum. Vol 11 Edisi Khusus Februari 2011. Semarang. Fakultas Hukum Universitas Islam Sultan Agung.

Mariam Darus Badrulzaman. 2001. Kompilasi Hukum Perikata. Jakarta: Citra Aditya Bakti

Onno W Purbo dan Wahyudi, Aang Arif. 2001. Mengenal E-commerce, Edisi Kedua. Jakarta: PT Elex Media Komputindo.

Peter Mahmud Marzuki. 2012. Pengantar Ilmu Hukum. Jakarta: Persada Media Grup

Rosa Agustina. 2008. "Kontrak Elektronik (E-Contract) dalam Sistem Hukum Indonesia" Jurnal Gloria Juris. Vol.8 No.1 Edisi 1 Januari-April 2008. Depok: Fakultas Hukum Universitas Indonesia.

Yosi Krisharyawan. 2015. "Tinjauan Hukum Mengenai Transaksi Jual Beli Melalui Situs Belanja (Online Shop) Menurut Kitab Undang-Undang Hukum Perdata dan Undang-Undang Nomor 8 Tahun 1999 tentang Perlindungan Konsumen" Privat Law Edisi 07, Januari-Juni 2015. Surakarta: Bagian Perdata Fakultas Universitas Sebelas Maret.

(https://www.Bukalapak.com/terms)

(https://komunitas.Bukalapak.com) 